\title{
Nodulation and nitrogenase activity of chickpea cultivar INRA 199 inoculated with different strains of Rhizobium ciceri
}

Pascal TILLARD \& Jean-Jacques DREVON

I.N.R.A., Laboratoire de Recherches sur les Simbiotes des Racines, place Viula, F 34060 Montpellier Cedex

\begin{abstract}
The nitrogen-fixing capacity of 12 collection strains of $R$. ciceri in symbiosis with chickpea INRA 199 was estimated in the greenhouse by comparison with plant growth in the absence of mineral nitrogen. The strains were separated into 4 groups of significantly different effectiveness. The magnitude of the energy loss in nodule hydrogen production by these strains was estimated to vary between 0.19 and 0.77 in a controlled environment. No hydrogenase activity was detected in any of the associations. In the field. hydrogen production represented $40 \%$ of the energy supply to nitrogenase activity during the growth cycle. A survey revealed considerable variation in nodulation, and in effectiveness of symbiosis, with the Rhizobium strains naturally present in soils where chickpea may be grown in future. In some fields there was no spontaneous nodulation. In the majority of fields, the mean dry weight of nodules per plant was around $200 \mathrm{mg}$ at flowering; maximum field nodulation was $700 \mathrm{mg}$ DW nodule plant .
\end{abstract}

Additional key words : Nitrogen fixation, Rhizobium, hydrogenase, ecophysiology.

\begin{abstract}
Nodulation et activité nitrogénase du pois chiche cultivar INRA 199 inoculé avec différentes souches de Rhizobium ciceri.

La capacité fixatrice d'azote de 12 souches de $R$. ciceri en symbiose avec le pois chiche (cultivar INRA 199) est mesurée en serre en comparant la croissance des plantes en absence d'azote minéral. Les souches sont classées en 4 groupes d'efficacités significativement différentes. En milicu contrôlé le pourcentage d'énergie perdu sous forme de production d'hydrogène par les nodosités varie de 0,19 à 0,77 . Aucune activité hydrogénase n'a ćté détectée sur ces souches.

Au champ la production d’hydrogène représente 40 p. 100 de l'énergie allouée à l'activité nitrogénase durant la vie de la plante. La fixation d’azote et la nodulation du pois chiche par les Rhizohium naturellement présents dans le sol varie considérablement. Dans certains des sols étudiés, il n'y a pas eu de nodulation spontanéc. Dans la majorité des cas, à la floraison, le poids sec moyen des nodosités par plantes est de $200 \mathrm{mg}$, le maximum mesuré étant de $700 \mathrm{mg}$.
\end{abstract}

Mots clés additionnels : Fixation d'azote, Rhizobium, hydrogénase, écophysiologie.

\section{INTRODUCTION}

Chickpea is one of the major grain legumes mostly grown in the world as a source of proteins for human beings. In Europe it is extensively grown in Turkey and Spain. There is some interest in extending its cultivation to other Mediterranean areas of this continent and in North Africa, since it is resistant to drought and grows in low fertility soils.

Like many other grain legumes, chickpea can fix atmospheric nitrogen in symbiosis with bacteria of the genus Rhizobium. The corresponding Rhizobia are specific and called R. ciceri (VAISHYA \& SanOrIA, 1972;
Gaur \& Sen, 1979). They differ in their $\mathrm{N}_{2}$ fixing capacities and the field yield of chickpea can be increased by seed inoculation with the most efficient strains (Okon et al., 1972 ; Patil \& Medhane, 1974 ; Corbin et al., 1977). The efficiency of the strains may be affected by the host cultivar (GAGENDRAGADKAR \& VAISHYA, 1983). These observations prompted us to screen collection strains of $R$. ciceri for their ability to fix nitrogen with the chickpea cultivar INRA 199 that has been selected for the south of France (WERY, 1986).

Acetylene reduction and hydrogen evolution were measured on the nodules obtained in the screening inorder to evaluate the magnitude of the energy loss due 
to nitrogenase $\mathrm{H}_{2}$ production which is considered as a major limitation of the $\mathrm{N}_{2}$ fixation efficiency (Evans et al., 1981 ; SALSAC et al., 1984).

In this work, field observations are also presented. $\mathrm{H}_{2}$ evolution and $\mathrm{C}_{2} \mathrm{H}_{2}$ reduction were measured on dry land cultivated chickpea. Nodulation with native Rhizobia in various soils was studied in order to evaluate the need for inoculation in areas where the plant may be grown in the future.

\section{MATERIALS AND METHODS}

\section{A. Rhizobium strains}

The $12 R$. ciceri strains of the screening assay are presented in table 1, with the geographical location of their initial isolation, when known and the collection from which each strain was obtained. Some of these strains were recently characterized by their serogroup (Kingsley \& Bohlool, 1983; ArsaC \& CleyetMAREL, 1986). The inoculants were prepared in the yeast extract mannitol medium (VINCENT, 1970). After surface sterilization in calcium hypochlorite $1,3 \%$ and germination on $1 \%$ agar enriched with YEM (Yeast extract mannitol medium) the seeds were inoculated by soaking in the liquid inoculant for $30 \mathrm{~min}$.

TABLE 1

Origin of Struins.

Origine des souches.

\begin{tabular}{ccc}
\hline \hline Name & Collection & Geographical origin \\
\hline IC 6 & ICRISAT & India \\
IC 165 & ICRISAT & India (Labalpur) \\
IC 2002 & ICRISAT & India \\
IC 2008 & ICRISAT & Great Britain \\
IC 2018 & ICRISAT & Turkey \\
IC 2091 & ICRISAT & Great Britain \\
USDA 3231 & USDA & USA (California) \\
27 A 8 & NITRAGIN & Mexico \\
R 18 & ETSIA & Argentina \\
829 & ETSIA & Spain \\
835 & IARI & Spain (Caceres) \\
H 45 & & \\
\hline \hline
\end{tabular}

- Strains were supplied by P. Dart from ICRISAT, H. Keyser from USDA, J. Burton from NITRAGIN, T. Ruiz-Argueso from ETSIA, M. Soto for R 18.

- Les souches ont été fournies par P. Dart de l'ICRISAT, H. Keyser de l'USDA, J. Burton de NITRAGIN, T. Ruiz-Argueso de l'ETSIA, et M. Soto pour la R 18.

\section{B. Plant cultivation}

Chickpea cultivar INRA 199 of desi type was grown in the greenhouse under the conditions described previously for soybean (KALIA \& DREVON, 1985). These conditions, in which growth and nodulation of chickpea were quite satisfactory, consisted of a one liter liquid nutrient root medium, removed every week, and complemented in the meanwhile with distilled water. The $\mathrm{pH}$ was maintained at neutrality with calcium carbonate $\left(0.7 \%\right.$ weight $\cdot$ weight $\left.{ }^{\prime}\right)$ and air was bubbled permanently into the medium at a flow rate of $400 \mathrm{ml} \cdot \min { }^{\prime}$. During the first three weeks of cultivation, the plants received $1 \mathrm{mM}$ urea; after this, the nitrogen was applied only in the $\mathrm{N}$-fed control treatment.

\section{C. $\mathrm{H}_{2}$ evolution and $\mathrm{C}_{2} \mathrm{H}_{2}$ reduction assays}

Nitrogenase activity was monitored by the acetylenereducing activity (ARA) method (HARDY et al., 1968). Since acetylene has been shown to inhibit nitrogenase activity in some legumes (MINCHIN et al., 1983), time course assays were performed on the INRA 199$R$. ciceri symbiosis with an open-flow device (DREVON et al., 1988). These was no detectable inhibition of $\mathrm{C}_{2} \mathrm{H}_{2}$ reduction by acetylene. This permitted a measure of ARA on intact plant in closed vessels according to a procedure described earlier for soybean (KALIA \& Drevon, 1985).

Assay of hydrogen evolution on intact plants gave us erratic results. Consequently, $\mathrm{H}_{2}$ evolution was assayed on excised nodulated roots (DREVON et al., 1983). ARA was measured in similar conditions to compute the apparent relative efficiency (aRE) according to SCHUBERT \& EVANS (1976) : aRE $=1$ - (rate of $\mathrm{H}_{2}$ evolution/rate of $\mathrm{C}_{2} \mathrm{H}_{2}$ reduction). Hydrogenase activity was checked on a suspension of bacteroids by measuring their aerobic consumption of $\mathrm{H}_{2}$ (DREVON et al., 1983).

\section{Nodulation survey}

In the field, ten contiguous plants were harvested at random locations at mid-flowering stage. Dry weights of shoots and nodules, when present, were individually measured after $48 \mathrm{~h}$ at $80^{\circ} \mathrm{C}$. Correlation coefficients between these two parameters and regression slopes, when significant, were computed in order to evaluate the effectiveness of the symbiotic interaction.

\section{RESULTS}

\section{A. Effectiveness of strains}

Variations in pod production by chickpea cv. INRA 199 inoculated with the different strains of $R$. ciceri are presented in figure 1 . These variations could be attributed to different levels of nitrogen fixation by the inoculants, since the nitrogen nutrition of the plant was the growth-limiting factor, as shown by the lower yield of the non-inoculated non-N-fertilized control treatment. From the statistical analysis on the data in figure 1 with the Newman and Keuls test, the strains were sorted into 4 groups with significantly different ability to fix nitrogen in these experimental conditions :

1. IC 2091, 829, R 18 and IC 2018 had the highest $N_{2}$ fixing activity. This activity met the $\mathrm{N}$ requirement of the plant as well as the weekly $1 \mathrm{mM}$ urea supply in the $\mathrm{N}$ control treatment.

2. IC 2008 and USDA 3231 constituted an intermediate group. 
3. IC 165, 27 A8, IC 6, 835 and H 45 had a low nitrogen fixation capacity, although their activity was still significant since the yield of plants inoculated with the strains was higher than the yield of the uninoculated plants.

4. IC 2002 was ineffective with chickpea INRA 199.

There was no apparent difference between the speed at which the strains formed nodules. Thus, the first nodules appeared about seven days after inoculation in all treatments.

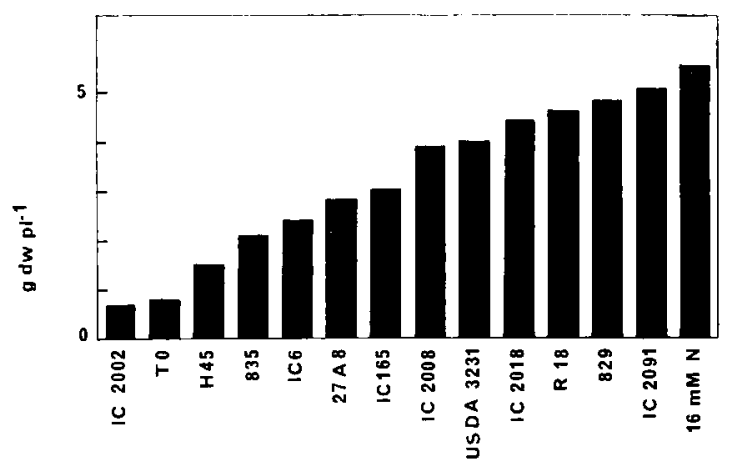

Figure 1

Effect of various strains of $\mathrm{R}$. ciceri on chickpea INRA 199 pod yield in the greenhouse.

Means of 6 replicates. Plants were grown hydroponically in the greenhouse. The $N$ treatment was I $\mathrm{mM}$ urea.

Effet de différentes souches de R. ciceri sur le poids sec de gousses du pois chiche (Cultivar INRA 199) cultivé en serre.

Les valeurs sont la moyenne de 6 répétitions. Les plantes ont été cultivées en serre en milieu hydroponique. Le traitement azoté était de $1 \mathrm{mM}$ d'urée.

\section{B. Nitrogenase activity}

The nitrogenase activity of the above four types of strains is shown in figure 2 . In the most active strains, activity was maximum 40-50 days after sowing, at the stage of early pod filling. Maximum ARA was $10.6 \mu \mathrm{mol} \mathrm{C}_{2} \mathrm{H}_{4} \mathrm{~h}^{1} \mathrm{pl}^{1}$ which is lower than for soybean in similar experimental conditions (KALIA \& DREVON, 1985). By contrast, the ineffective IC 2002 strain had almost no detectable ARA during the entire growth cycle.

$\mathrm{H}_{2}$ evolution and ARA by excised nodulated roots were measured for some representative strains of this screening between 40 and 45 days after sowing. The results in table 2 show that the strains having the highest effect on pod yield were the ones having the highest nitrogenase activity at these dates. All strains evolved significant amounts of hydrogen ; the apparent relative efficiency of excised nodules varied between 0.19 and 0.77 . No hydrogenase activity was detected on the bacteroids from the nodules formed by the strains of the screening (data not shown).

In the field (fig. 3), nitrogenase activity started later after sowing because the germination process was slowed by the cold temperature of the 1984 month of March. Nitrogenase activily increased regularly during the following 30 days but stopped abruptly due to lack

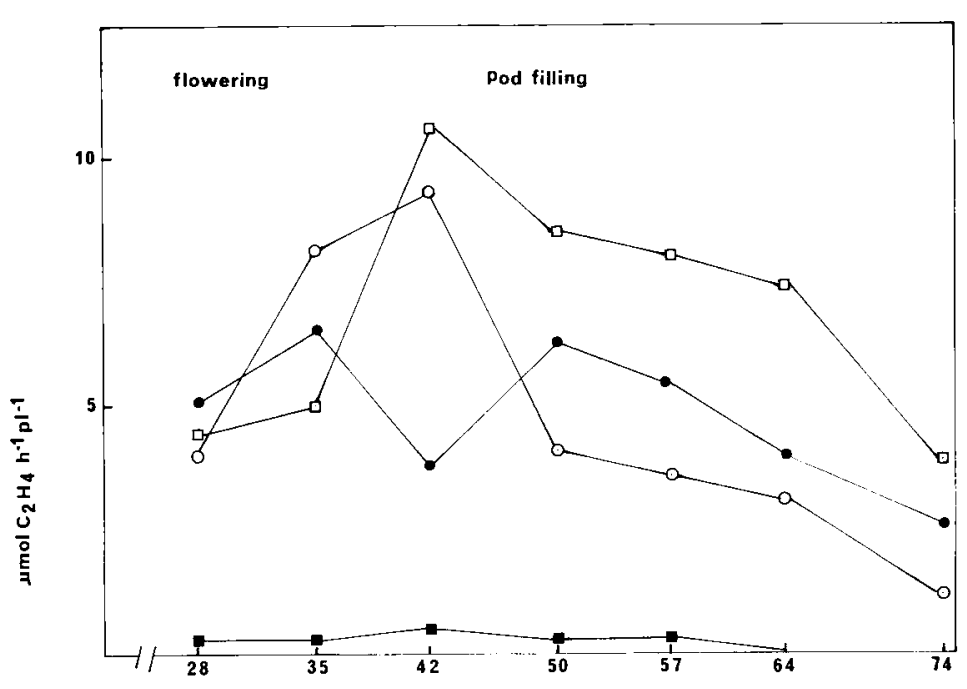

Figure 2

days after sowing

Acetylene-reducing activity of chickpea INRA 199 over is growth cycle in the greenhouse.

Means of 4 replicates. $\mathrm{R}$ ciceri strains were : - IC $6 ;-0-R 18 ;-\mathrm{L}_{-}$ USDA 3231; - - IC 2002.

Mesure de l'activité réductrice d'acétylène du pois chiche (cultivar INRA (199) pendant la croissance des plantes en serre.

Les souches de $\mathrm{R}$. ciceri sont :- - IC $6 ;-0-R 18 ;-[1$ - USDA 3231

- IC 2002. Les valeurs sont la moyenne de 4 répétitions.

of water after this date. Similar drought limitation of chickpea nitrogen fixation was observed in 1983 (COMERE, personal communication). Measurements of hydrogen evolution show that during the period of fixation, about $40 \%$ of the energy supplied to nitrogenase activity was lost in hydrogen production (fig. 3).

Winter-sown chickpea may have a higher nitrogen fixation. Indeed, their nodule fresh weight was significantly higher at a similar date than for spring-sown chickpea: on June 15 th, it was $8.0 \pm 2.2 \mathrm{~g}$ fw nodules

TABLE 2

Nitrogenase activity $\left(\mathrm{C}_{2} \mathrm{H}_{2}\right.$ reduction and $\mathrm{H}_{2}$ evolution) and apparent relative efficiency of some representative strains from the screening.

Activité nitrogénase (réduction de $\mathrm{C}_{2} \mathrm{H}_{2}$ e't émission de $\mathrm{H}_{2}$ ) et efficacilé relative apparente de souches représentatives du criblage.

\begin{tabular}{|c|c|c|c|}
\hline Strains & $\mu \mathrm{mol} \mathrm{C}_{2} \mathrm{H}_{4} \mathrm{~h}^{\mathrm{l}} \mathrm{pl}^{\prime}$ & $\mu \mathrm{mol} \mathrm{H}_{2} \mathrm{~h}^{\prime} \mathrm{pl}^{\mathrm{l}}$ & aRE \\
\hline IC 2002 & 0.21 & 0.17 & 0.19 \\
\hline H 45 & 1.61 & 0.58 & 0.63 \\
\hline 835 & 5.10 & 1.40 & 0.73 \\
\hline IC 6 & 3.70 & 1.12 & 0.70 \\
\hline 27 A 8 & 6.00 & 1.80 & 0.70 \\
\hline IC 165 & 7.18 & 1.64 & 0.78 \\
\hline IC 2008 & 5.83 & 2.25 & 0.61 \\
\hline USDA 3231 & 10.60 & 3.79 & 0.63 \\
\hline IC 2018 & 15.25 & 3.50 & 0.77 \\
\hline R 18 & 8.30 & 1.82 & 0.78 \\
\hline 829 & 9.20 & 3.50 & 0.62 \\
\hline IC 2091 & 9.70 & 4.20 & 0.57 \\
\hline
\end{tabular}

Means of 4 replicates. Plants were $40-45$ days old during the assay. Lowest significant differences are $4.25 \mu \mathrm{mol} \mathrm{C}_{2} \mathrm{H}_{4} \mathrm{~h}^{1} \mathrm{pl}^{1}, 1.21 \mu \mathrm{mol}$ $\mathrm{H}_{2} \mathrm{~h}^{1} \mathrm{pl}{ }^{1}$ and 0.07 for aRE.

Les données sont les moyennes de 4 répétitions. Les plantes étaient âgées de $40-45$ jours au moment de la mesure. Les plus petites différences significatives sont de $4,25 \mu \mathrm{mol} \mathrm{C}_{2} \mathrm{H}_{4} \mathrm{~h}^{1} \mathrm{pl}^{1}, 1,21 \mu \mathrm{mol}$ $\mathrm{H}_{2} \mathrm{~h}^{\prime} \mathrm{pl}^{1}$ et 0,07 pour l'ERa. 


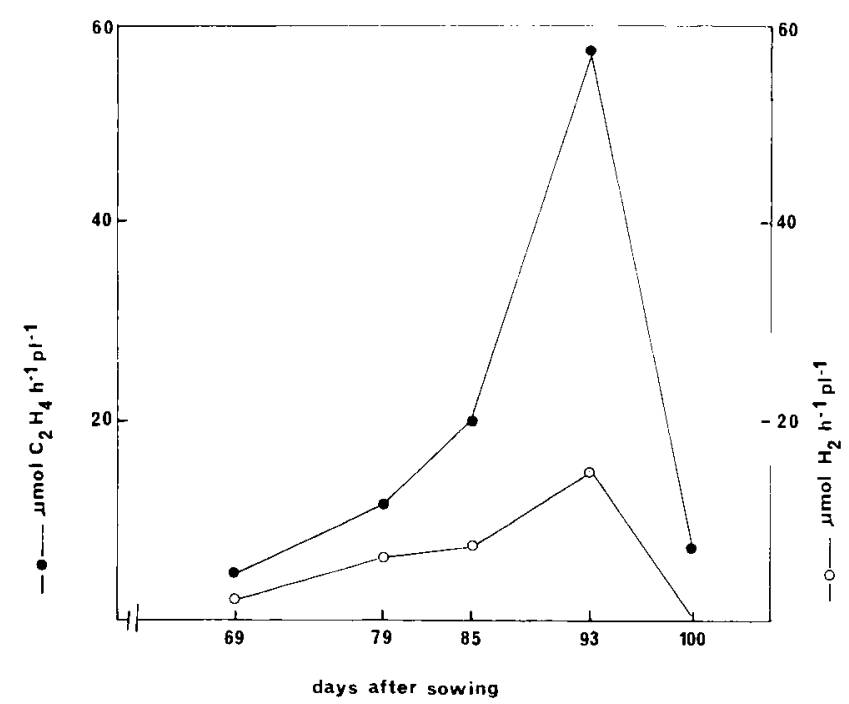

Figure 3

Acetvlene-redacing activity and hydrogen evolution of chickpea cr. INRA 199 in the field.

Means of 8 replicates. Strains of Rhizobium nodulating chickpea were found in the soil.

Evolution de l'activité réductrice d'acétylène et de lhydrogène d' pois chiche au champ.

Les valeurs sont la mogenne de 8 répétitions. Le pois chiche a été nodule par des souches de Rhizobium naturellement présentes dams lo sol.

$\mathrm{pl}^{\prime}$ on winter-sown plants compared with to $2.5 \pm 1.2 \mathrm{~g}$ fw nodules pl' ${ }^{\prime}$ on spring-sown chickpea. The comparison of ARA between winter and spring sown plants would be of major interest.

\section{Nodulation survey}

The nodulation and shoot dry weights of plants harvested at the flowering stage in 20 fields of the Mediterranean area are shown in table 3. Nodule mass varied considerably. In the majority of the fields, it ranged between 90 and $300 \mathrm{mg} \mathrm{dw} \mathrm{pl} \mathrm{'.} \mathrm{In} \mathrm{three} \mathrm{loca-}$ tions it was higher than $500 \mathrm{mg} \mathrm{dw} \mathrm{pl} \mathrm{'.} \mathrm{Fields} 17.18$ and 20 had no or insignificant nodule mass: eilher specific effective strains were absent in these fields, or nodulation was strongly inhibited by some pedoclimatic factor.

The mean number of nodules per plant varied from 0 to 52. It was not significantly related to mean nodule mass, some plants having a few big nodules (see field 7), others having numerous small nodules (see field 10). Field 18 showed up as a case of numerous but ineffective nodulation related to a very limited mass of aerial parts.

Plant growth also differed in the various fields. In the overall survey, it did not correlate with mass or number of nodules per plant. This absence of correlation suggests that nitrogen fixation was not the major limiting growth factor of field-grown chickpea, at least in some locations of the survey. This can be illustrated by the comparison between fields 4 and 5 which had similar nodule mass, although shoot dry weight was almost

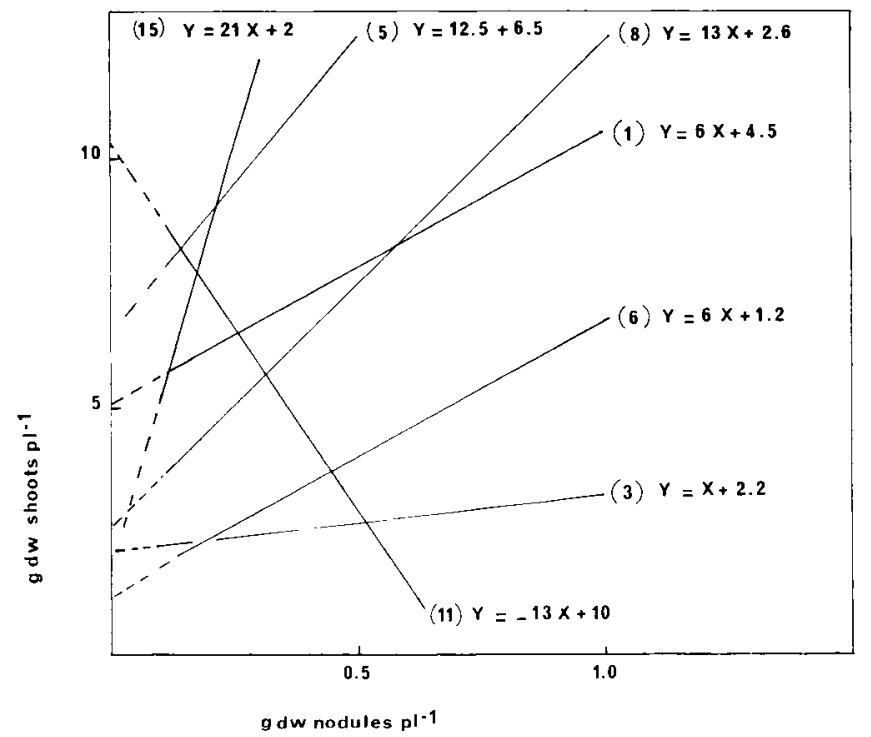

Figure 4

Linear regressions between shoot and nodule weight in survey fields where the two parameters were significantly correlated.

Las régressions linéaires entre le poids sec des parties aériennes et les nodositées dans l'enquéte au champ sont corrélées de façon significative.

three times higher in field 5 ; some environmental factor may have limited the plant response to nodulation in field 4. However an alternate interpretation would be that the nodule-specific activity of the native strains varied from one location to another.

In some locations the soil might have been the major source of $\mathrm{N}$ inhibiting nodulation. Fields 7 and 11 , in which nodule numbers were low and plant growth was high, could be such cases.

In some fields of the survey, shoot and nodule dry weights were significantly correlated (fig. 4). In the case of soil $\mathrm{N}$ limitation, such a correlation indicates that nitrogen fixation was the major limiting growth factor. The intercept of the curve on the shoot dry weight axis may correspond to plant growth in the absence of nodulation and therefore to soil $\mathrm{N}$ contribution. The slope could be an evaluation of nodulation efficiency, a steep slope corresponding to highly efficient symbiosis. Thus a similar increase of nodule mass could correspond to a faster growth of plants in the case of a steep slope than in the case of a low slope. However the steepest slopes were not necessarily associated with the highest mean shoot dry weights : see for example field 8 compared to field 1 . Soil nitrogen, native strain effectiveness and pedoclimatic factors might be the cause of these discrepancies. Nitrogen fixation would be low either because of poor effectiveness of the symbiosis or because of limitation of its capacity by adverse environmental factors. Some confirmation of this interpretation was found in field 11 , where low nodulation presumably due to high soil $\mathrm{N}$ content was associated with a negative slope and consequently ineffective nodulation : thus nitrate assimilation is known to inhibit not only nodulation, but also nitrogenase activity (GIBSON, 1976). 
TABLE 3

Growth and nodulation of plants harvested in various chickpea fields in the south of France.

Croissance et nodulation des plantes récoltées dans divers champs de pois chiche dans le Sud de la France.

\begin{tabular}{|c|c|c|c|}
\hline Location & Nodule pl ${ }^{\prime}$ & $\mathrm{g} D W \operatorname{nod} \mathrm{pl}^{\prime}$ & g DW shoot pl \\
\hline 1. La Valette (Hérault) & $29 \pm 16$ & $0.70 \pm 0.60$ & $9.02 \pm 5.90$ \\
\hline 2. Montpellier (Hérault) & $52 \pm 13$ & $0.68 \pm 0.50$ & $10.40 \pm 3.60$ \\
\hline 3. Gareoult (Var) & $13+7$ & $0.50+0.50$ & $2.80 \pm 0.80$ \\
\hline 4. Gareoult (Var) & $15 \pm 10$ & $0.34 \pm 0.34$ & $3.30 \pm 0.78$ \\
\hline 5. Digne (Haute-Provence) & $21 \pm 10$ & $0.32 \pm 0.20$ & $9.77 \pm 4.43$ \\
\hline 6. Gareoult (Var) & $34 \pm 22$ & $0.31 \pm 0.21$ & $3.48 \pm 0.75$ \\
\hline 8. Carmejane (Haute-Provence) & $36 \pm 17$ & $0.22 \pm 0.07$ & $5.60 \pm 1.30$ \\
\hline 9. Les Mées (Haute-Provence) & $37 \pm 12$ & $0.20 \pm 0.08$ & $3.32 \pm 1.41$ \\
\hline 10. Puyricard (Bouches-du-Rhône) & $40 \pm 14$ & $0.17 \pm 0.05$ & $1.97 \pm 0.71$ \\
\hline 11. Mauguio (Hérault) & $3 \pm 6$ & $0.15 \pm 0.2$ & $8.30 \pm 8.10$ \\
\hline 12. Valensole (Haute-Provence) & $12 \pm 5$ & $0.15 \pm 0.07$ & $7.40 \pm 2.57$ \\
\hline 13. Carmejane (Haute-Provence) & $12 \pm 5$ & $0.15 \pm 0.07$ & $7.40 \pm 2.57$ \\
\hline 14. Figuiere (Haute-Provence) & $17 \pm 11$ & $0.12 \pm 0.0$ & $1.86 \pm 0.65$ \\
\hline 15. Thoard (Haute-Provence) & $5 \pm 5$ & $0.10 \pm 0.09$ & $5.20 \pm 2.97$ \\
\hline 17. Valensole (Haute-Provence) & $3 \pm 7$ & $0.09 \pm 0.1$ & $4.52 \pm 1.66$ \\
\hline 18. Puyricard (Bouche-du-Rhône) & $17 \pm 10$ & $0.03 \pm 0.02$ & $0.33 \pm 0.08$ \\
\hline 19. Carmejane (Haute-Provence) & $6 \pm 5$ & $0.02 \pm 0.01$ & $0.97 \pm 0.22$ \\
\hline 20. Digne (Haute-Provence) & 0 & 0 & $1.76 \pm 0.41$ \\
\hline
\end{tabular}

Means \pm standard deviations of 10 replicates; plants were harvested at the mid flowering stage.

Les données sont les moyennes \pm écart type 10 répétitions; les plantes ont été récoltées au stade mi-floraison.

\section{DISCUSSION}

The collection strains of $R$. ciceri varied in their capacity to fix nitrogen with chickpea cv. INRA 199. Strain H45, known as an efficient strain (GAGENDRAGADKAR \& VAISHYA, 1983), had low nitrogen fixation in this screening, which suggests a negative effect of the macrosymbiont on the expression of this strain's capacity to fix nitrogen. However INRA 199 seemed to be able to exploit fully the nitrogen fixation process, since its yield in the presence of the best fixing strains in this assay was similar to that obtained with combined nitrogen. Field inoculation assays are needed to check the ranking of strains in agricultural conditions and evaluate their effect on yield in fields where there is no $R$. ciceri, and in fields where the introduced strain will have to compete with native Rhizobia which are able to nodulate chickpea.

The relative amounts of hydrogen evolved by these strains were of the same order of magnitude (MINGUEZ \& Ruiz-ARgueso, 1980) or lower (SindHu et al., 1986) than those described previously. They represent a loss of 25 to $60 \%$ of the energy required for nitrogenase activity. However in situ measurement of $\mathrm{H}_{2}$ evolution is needed to check that the high production of $\mathrm{H}_{2}$ by excised nodulated roots was not an artefact. Thus excision is known to modify the oxygen supply of the bacteroids (SHEEHY et al., 1985), which is a determinant factor of the apparent relative efficiency of soybean
(DREVON et al., 1982). The absence of hydrogenase activity in the $R$. ciceri strains of this screening, in addition to previous similar observations in other isolates (Minguez \& Ruiz-Argueso, 1980 ; Sindhu et al., 1986) suggests that the frequency of $\mathrm{Hup}^{+}$(hydrogenase uptake positive) strains is low in the symbiosis with chickpea, which is not the case in all Rhizobium species (EISBRENNER \& EVANS, 1982).

The field survey showed that $R$. cicer $i$ was absent in some locations of possible cultivation of chickpea in France. Inoculation might be necessary although the observed absent or poor nodulation could be due to some adverse environmental factor. More information on soil and climate would be necessary for a more detailed analysis in a further survey. It would help to improve chickpea nitrogen fixation in its area of extension and to determine where inoculation would be beneficial.

Reçu le 17 mars 1987. Accepté le 19 octobre 1987.

\section{ACKNOWLEDGEMENTS}

The authors thank Drs J. BuRTON, P. DART, H. KEYSER and T. RuIZ-ARGueso for supplying the strains. They are indebted to the farmers and to J. WERY and V. PLouX for the field survey. The manuscript was carefully typed by Mrs ROBERT and the figures drawn by Mrs MeKBEL. 
Arsac J. F., Cleyet-Marel J. C., 1986. Serological and ecological studies of Rhizobium spp. (Cicer arietinum $\mathrm{L}$.) by immunofluorescence and ELISA technique: competitive ability for nodule formation between Rhizobium strains. Plant Soil, 94, 411-423.

Corbin E. J., Brockwell J., Gault J. R., 1977. Nodulation studied on chickpea (Cicer arietinum L.). Aust. J. Exp. Agric. Anim. Hust., 17, 126-134.

Drevon J. J., Frazier L., Russell S. A., Evans H. J., 1982. Respiratory and nitrogenase activities of soybean nodules formed by hydrogen uptake negative (Hup-) mutant and revertant strains of Rhizobium japonicum. Plant Physiol., 70, 1341-1346.

Drevon J. J., Tillard P., Salsac L., 1983. Influence de 2 espèces de légumineuses, $V$. radiata et $V$, unguiculata sur l'activité hydrogénase de la souche CB 756 de Rhizobium du groupe " cowpea ». C.R. Acad. Sci., Paris, 296, 979-982.

Drevon J. J., Kalia V. C., Heekmann M. O., Tillard P., Pedelahore P., 1988. In situ open-flow assay of soybean root nodular acetylene reduction activity; infuence of acetylene and oxygen. Plant Phvsiol. Biochem. (in press).

Eisbrenner G., Evans H. J., 1982. Aspects of hydrogen metabolism in nitrogen-fixing legumes and other plant microbe associations. Ann. Rev. Plant Physiol., 34, 105-136.

Evans H. J., Purohit K., Cantrell M. A., Eisbrenner G., Russell S. A., Hanus F. J., Lepo J. E., 1981. Hydrogen losses and hydrogenases in nitrogen-fixing organisms. In Current Perspectives in Nitrogen Fixation. A. H. Gibson and W. E. Newton, Eds, Griffin Press, Canterra, 84-96.

Gagendragadkar G. R., Vaishya U. K., 1983. Interaction between Rhizobium strains and chickpea varieties. Indian J. Agric. Sci, 53, 356-357.

Gaur Y. D., Sen A. N., 1979. Cross inoculation group specificity in Cicer-Rhizobium symbiosis. New Phytol., 83, 745-754.

Gibson A. H., 1976. Recovery and compensation by nodulated legumes to environmental stress. In Symbiotic Nitrogen Fixation. P. S. Nutman (Ed.), Cambridge University Press, Cambridge, 385-404.

Hardy R. W. F., Holsten R. D., Jackson E. K., Burns R. G., 1968. The acetylene-ethylene assay for $\mathrm{N}_{2}$ fixation : laboratory and field evaluation. Plant Physiol., 43, 1185-1207.
Kalia V. C., Drevon J. J., 1985. Variation in nitrogenase activity $\left(\mathrm{C}_{2} \mathrm{H}_{2}\right.$ reduction) during in situ incubation of root nodules of Glvcine max (L.) Merr. C.R. Acad. Sci., Paris, 301, 591-596.

Kingsley M. T., Bohlool B. B., 1983. Characterization of Rhizobium sp. (Cicer arietinum L.) by immunofluorescence, immunodiffusion and intrinsic antibiotic resistance. Can. J. Microbiol., 29, 518-526.

Minchin F. R., Witty J. W., Sheehy J. E., Muller M., 1983. A major error in the acetylene reduction assay: decrease in nodular nitrogenase activity under assay conditions. J. Expl. Bot., 34, 641-649.

Minguez M. I., Ruiz-Argueso T., 1980. Relative energy efficiency of nitrogen fixation by nodules of chickpeas (Cicer arictimum $\mathrm{L}$.) produced by different strains of Rhizobium. Curr. Microbiol., 4, 169-171.

Okon Y., Eshel Y., Henis Y., 1972. Cultural and symbiotic properties of Rhizobium strains isolated from nodules of Cicer arietinum L. Soil. Biol. Biochem, 4, 165-170.

Patil P. L., Medhane N. S., 1974. Seed inoculation studies in gram (Cicer arietinum L.) with different strains of Rhizobium sp. Plant Soil. 50, 553-566.

Salsac L., Drevon J. J., Zengbé M., Cleyet-Marel J. C., Obaton M., 1984. Energy requirement of symbiotic nitrogen fixation. Physiol. Vég., 22, 509-521.

Schubert K. R., Evans H. J., 1976. Hydrogen evolution : a major factor affecting the efficiency of nitrogen fixation in nodulated symbionts. Proc. Nat. Acad. Sci. USA, 73, 1207-1211.

Sheehy J. E., Minchin F. R., Witty J. F., 1985. Control of nitrogen fixation in a legume nodule : an analysis of the role of oxygen diffusion in relation to nodule structure. Ann. Bot., 55, 549-562.

Sindhu S. S., Dadarwal K. R., Dadhiya B. S., 1986. Hydrogen evolution and relative efficiency in chickpea (Cicer arietinum L.) : effect of Rhizobium strain, host cultivar and temperature. Indian $J$. Exp. Biol., 24, 416-420.

Vaishya U. K., Sanoria C. K., 1972. Specificity and efficiency of Rhizobium cultures of Bengal gram. Indian J. Microbiol., 12, 133-141. Vincent J. M., 1970. A manual for the practical study of root nodule bacteria. Blackwell, Oxford.

Wery J., 1986. Un pois pas si chiche que celà. Bull. Fnams Sem., 97, 32-35. 